\title{
Las Antillas, nuevamente, «entre imperios» y de cómo enfrentarse al insularismo racialista para alcanzar el objetivo de una confederación regional
}

\author{
por \\ José F. Buscaglia Salgado \\ University at Buffalo
}

\begin{abstract}
A principios del siglo XXI los pueblos antillanos vuelven a ser agentes de poca monta en un proceso de reordenamiento geopolítico a escala mundial dentro del cual el Caribe es un escenario de mayor relevancia. Un nuevo periodo de "entre imperios» ya se vislumbra en el repliegue de los Estados Unidos y el alza de la influencia de China en la región. Este trabajo, ubicado en la intersección de la historia, los estudios culturales y la macropolítica, es una reflexión amplia que rescata el legado del proyecto decimonónico de la Liga Antillana para proponer un posible realineamiento de fuerzas a nivel regional con miras hacia la posibilidad real de romper el complejo de insularismo, la cultura del racialismo y la sujeción política de medio milenio a potencias ultramarinas.

Palabras clave: Antillas; Confederación Antillana; Caribe; China; Doctrina Monroe; Indias Occidentales; insularismo; racialismo; racismo; Liga Antillana.
\end{abstract}

«Cuando se quiere una tortilla, hay que romper los huevos»

Ramón Emeterio Betances a Eugenio María de Hostos, $1869^{1}$.

Desde la irrupción de la empresa colonial europea y la imposición del cristianismo en los territorios arahuacos ${ }^{2}$ de lo que han pasado a conocerse como las Antillas Mayores y hasta más allá del fin de la Guerra Fría, el Caribe

\footnotetext{
${ }^{1}$ Hostos, 1969, tomo 14: 70.

2 Prefiero identificar a estos pueblos por su lengua y no por los apelativos «taíno»o «caribe» impuestos por los colonizadores cristianos en el siglo XV. Ver Hulme, 1992: 13-43.
} 
ha sido un teatro geopolítico accidentado y plegadizo. Allí se han encontrado y sucedido en un relevo ininterrumpido de reclamos hegemónicos los intereses de las principales potencias del Atlántico Norte en función de lo que hoy se puede ver como un grueso palimpsesto de proyectos caracterizados por períodos de expansión violenta y decadencia inevitable. Pudiera decirse que las sociedades antillanas no conocen otra realidad que la vida entre imperios, concepto este que debe entenderse en un doble sentido que no solo incluye el sometimiento repetido. También habría que hablar del juego amplio que se ha dado continuamente dentro y fuera de las competencias jurisdiccionales de un estado colonial y otro, en las zonas geográficas y culturales abiertas y amparadas por la cimarronería de ayer y el contrabando de siempre, así como también de aquellos proyectos políticos que en momentos clave han cuestionado el orden colonial imperante.

Esa tensión entre la sujeción y la fuga, el ámbito oficial y el contrabando de mercancías e ideas, sigue conjugándose en un Caribe que a principios del siglo XXI se encuentra otra vez en la antesala de un reordenamiento geopolítico a escala mayor. Ciertamente estamos entrando en un nuevo período de «entre imperios» que ya se vislumbra claramente por un lado en la indiferencia y el repliegue de los Estados Unidos de una zona que durante el último siglo esa potencia reclamó en exclusividad y, por otro, en el alza en la inversión y la influencia de China en la región. Este trabajo es una reflexión amplia que mira hacia el pasado y busca en la idiosincrasia de los pueblos antillanos y en la posición estratégica que ocupan las islas, una salida viable y agenciada de esta recurrente encrucijada. Propongo que, a diferencia de otros momentos de transición y muy a pesar de los grandes retos que puedan enfrentarse, los pueblos del Caribe y, más específicamente los de las Antillas y las Bahamas, encaran por primera vez en su historia la posibilidad real de romper definitivamente con el cerco de la sujeción a potencias ultramarinas. Dos grandes escollos ideológicos, muy cercanos uno del otro, amenazan la navegación en esa ruta y deben ser sorteados previo a tomar derrota: la herencia cultural racialista y el complejo del insularismo. Pero antes habrá que trazar el curso de las corrientes coloniales que hicieron surgir del fondo del mar estos grandes bancos de arena.

De COLÓN AL OCASO DE LA «COLONIALIDAD»

Como hijas primogénitas del colonialismo y de la plantación esclavista las Antillas son también las amas de llave de la «colonialidad del poder» ${ }^{3}$. Me

\footnotetext{
3 Tomo el término de Quijano, 2000.
} 
refiero a la aparente inmutabilidad de ese complejísimo sistema que surgió en la modernidad temprana para justificar la división del trabajo y el racionamiento de los derechos entre un ideal de hombre (y, en menor grado, de mujer) europeo, vástago de pueblo escogido en el sentido abrahámico y cristiano, $\mathrm{y}$ un abanico de identidades «otras» fruto del más delirante capricho mercantil. Las varillas de este engendro variopinto serían rigurosamente codificadas en razas y castas para aventar a sus portadores lejos del trabajo asalariado. Por medio de esa descalificación legalista y seudomoral se condenaría a vastos sectores de la humanidad a la destitución sistemática, tanto política como económica, comenzando con el «negro» como sinónimo de esclavo y como «raza» primigenia de la modernidad. Hablar de aquello que de colonial tiene el poder es entender que todavía hoy estas divisiones se mantienen vigentes aún cuando el colonialismo clásico ha eclipsado como modelo político sustentable.

A lo largo de su historia los pueblos antillanos se han enfrentado a las trampas de la colonialidad del poder buscando precisamente en los intersticios de «entre imperios» espacios donde reclamar y ejercer derechos para potenciar modelos alternativos de autogobierno. Fue así como la desestabilización política causada por el estallido de la revolución en Francia dio paso en el Saint-Domingue de finales del siglo XVIII a una lucha encarnizada contra la plantación esclavista que intentó también desactivar los principales dispositivos de la ideología racialista. La defensa de la universalidad de los derechos humanos y del ciudadano en las Antillas, hecha ley en la Constitución de SaintDomingue de 1801, fue un intento de fuga que abrió una enorme brecha, no ya entre los defensores de la causa republicana y los monárquicos, sino también entre los partidarios del racialismo, indistintamente de sus lealtades políticas, $\mathrm{y}$ aquellos que entendían los «derechos del hombre» como verdaderamente universales y no exclusivos del hombre «blanco» o europeo. La revolución en las Antillas fue por tanto doblemente revolucionaria comparada con el proceso ultramarino que en las calles de París le sirvió de detonante e infinitamente más visionaria que en las colonias esclavistas británicas de Norte América donde los partidarios de la libertad supieron circunscribir desde un principio el ejercicio de todo derecho ciudadano a los «blancos».

La primera constitución antillana (y latinoamericana) hizo de todos los habitantes de Saint Domingue hombres y mujeres libres y franceses. Pero la guerra de devastación lanzada bajo el grito de «icortad las cabezas y quemad las haciendas!» desembocó rápidamente en un cataclismo económico que llevó a exigir la sujeción más firme de los autoemancipados bajo el sable de libertadores convertidos en caudillos. El primero fue Toussaint L'Ouverture, nombrado gobernador constitucional y vitalicio en 1801. Su sucesor, JeanJacques Dessalines se autoproclamó Emperador Jacques I en 1804. El regreso 
a la plantación bajo formas rebuscadas de dudosa legalidad y la presión de los reclamos populares de libertad y trabajo adornaron las puntas del bicornio de los nuevos dictadores. Entre medio y en la sobra, el proyecto de levantar estados soberanos sobre islas de factorías coloniales con vastas zonas de frontera escondió la voluntad de orden y la ambición de poder en la entelequia renovadora del racialismo. La impronta de las instituciones del antiguo régimen fue marcando con su carimbo ardiente la piel de los estados débiles y desamparados que surgieron de las cenizas en La Española. Así fue como la colonialidad intentó hacerse ley contra la más iracunda resistencia, causando grandes dislocaciones y una anarquía generalizada que dilataría considerablemente un relevo imperial entre las potencias europeas y los Estados Unidos que tardó en cuajar prácticamente todo el siglo XIX.

Durante ese período la búsqueda de una vía alterna que trocara el patrón establecido del relevo imperial por una transición hacia la libertad sostenible fue trazada ya a mediados de siglo por un grupo amplio de republicanos comprometidos que rechazaban tajantemente la tendencia caudillista sobradamente evidente y que, encabezada por Dessalines cobraba forma en una relación nutrida de caciques menores aunque igual de egomaníacos como Pedro Santana en la República Dominicana y Carlos Manuel de Céspedes en Cuba. Alarmados por la creciente injerencia de los Estados Unidos en la zona, estos hombres y mujeres hicieron causa común en el proyecto confederativo de la llamada Liga Antillana ${ }^{4}$. Fiel al republicanismo petioniano ${ }^{5}$ y financiada desde Port-au-Prince, Nueva York y París, esta fue la causa común que propulsó la que denomino como Guerra de los Cien Años Caribeña ${ }^{6}$, cuyos escenarios principales fueron recorriendo las Antillas Mayores en lo que hoy conocemos como la Revolución Haitiana (1791-1804), las guerras de independencia (18211822, 1844-1856) y la Guerra de la Restauración de la República Dominicana (1863-1865), y la Guerra de Independencia de Puerto Rico y Cuba (18681898). Ese proyecto pan-antillano que buscaba poner fin a la plantación y a la herencia del racialismo para asegurar la soberanía popular a nivel regional

\footnotetext{
${ }^{4}$ Valga aclarar que este nombre procede del calificativo utilizado por los servicios de espionaje españoles para poner en tela de juicio los motivos y la empresa misma de los confederados antillanos y que no fue nunca el nombre dado por los integrantes de un plan complejo y políticamente delicado que se obró principal y casi exclusivamente dentro de la clandestinidad. El nombre proviene específicamente de los documentos contenidos en el archivo del militar español Camilo García de Polavieja y otras fuentes directamente relacionadas. Ver Archivo General de Indias (AGI), Diversos, S. 2, y Diversos, 8, r. 1.

${ }^{5}$ Alexandre Sabès Pétion (1770-1818), fue el primer presidente de la República de Haití (1806-1818).

${ }^{6}$ Buscaglia Salgado, 2014.
} 
fue sofocado violentamente y condenado al olvido con la implantación de lo que he dado por renombrar la «Pax Usoniana» en $1898^{7}$.

La Pax Usoniana fue un golpe de mancuerda que detuvo violentamente el impulso creativo y los reclamos de justicia social en función de una modernidad poscolonial por parte de amplios sectores en los pueblos de las Antillas Mayores. El bombardeo de San Juan, el hundimiento de la flota española en Santiago de Cuba y la hambruna sistemática a la que fue reducido el Ejército Libertador cubano por los invasores usonianos obligó a recular en dirección de un legado racialista y colonial que pudo haberse dejado atrás con la toma de La Habana por las fuerzas mambisas cubanas que tocaban a sus puertas ya antes de la voladura del USS Maine, hecho que sirvió de justificante para la invasión del Caribe por parte de los Estados Unidos. Si el proyecto de los confederados antillanos pretendió rehacer el mapa entero de la cuenca para hermanar a los pueblos que la experiencia colonial había segregado, las fuerzas militares de Estados Unidos irrumpieron en la zona para restaurar y reforzar las fronteras de las antiguas colonias, relanzar la plantación a escala industrial con la central azucarera y promover gobiernos racistas liderados por minorías étnicas y caudillos, gordos o flacos, pero siempre leales a Washington.

Aquí suele siempre ponerse como ejemplo la Enmienda Platt (1903) que en efecto hizo de Cuba un protectorado usoniano. Pero el estudio de Julian Go, que compara la experiencia filipina con la puertorriqueña, demuestra cómo verdaderamente se gestionó el acuerdo mediante el cual las fuerzas miliatres usonianas delegaron en la élite boricua, para ellos lo suficientemente White o «blanca», el proceso de Americanization de una gruesa capa popular que, por estar compuesta principalmente de los llamados Blacks o «negros» y ser culturalmente de «raza» hispánica «mestiza» o mongrel, fue relegada por los nuevos amos imperiales al margen de la civilización. De ahí que el llamado proceso de «americanización» se proyectase como una vía para la redención moral, e incluso racial, de una prole diversa que las élites criollas difícilmente intentaban aglutinar bajo el concepto sentencioso de «la gran familia puertorriqueña ${ }^{8}$ mientras transaban su proletarización bajo sueldos de miseria y unas largas temporadas de «tiempo muerto» o sin trabajo en los cañaverales. Viéndolo desde la perspectiva del proyecto antillanista, el siglo XX bajo la Pax Usoniana sería un siglo de trágico retroceso en el Caribe.

${ }^{7}$ Utilizo el neologismo de usoniano y el nombre de Usonia, tomado de las siglas U.S.A. (United States of America) para referirme a todo lo perteneciente a los Estados Unidos de América. Ver Buscaglia Salgado, 2003.

${ }^{8}$ Go, 2008. 
Hoy, a poco más de un siglo de aquellos acontecimientos, presenciamos por tercera o cuarta vez otro fin de imperio en la zona y en la América toda. Queda sobradamente en evidencia que Estados Unidos es ya incapaz de hacer cumplir la llamada Doctrina Monroe por medio de la cual ese país se reservaba el derecho a intervenir militarmente en cualquier país o territorio que intentara poner coto a su política de expansionismo mercantil y político. Podemos decir que asistimos ahora a la inauguración de una nueva fase de transición y relevo imperial donde la Pax Usoniana se desdibuja frente a la incorporación de Brasil como joven potencia hemisférica y la vorágine que lanza China sobre el continente en busca de recursos naturales y nuevas rutas comerciales cada vez más eficientes y caudalosas.

Cabría preguntarse entonces si la merma del poderío usoniano pudiera servir para rescatar algunos de los valores y objetivos del proyecto confederativo de la Liga Antillana ${ }^{9}$. El reto es enorme pues, para empezar, se trata de un proyecto cuyos pormenores sus principales propulsores se llevaron a la tumba y que, al haber sido borrado de los mapas imperiales usonianos y de los manuales de historia nacional en las islas, ha sido casi totalmente extirpado de la memoria colectiva. Además, el ejercicio de recordar el futuro debe ser precedido por un acto de auto crítica severo y nada grato que nos lleve a los isleños a reconocer y querer superar los vicios adquiridos en todo un siglo de camino en sentido contrario. Solo así sería posible pensar en la probabilidad de que el derrumbe de la hegemonía euro-usoniana-criolla fuera a dar paso a lo que pudiera llegar a ser un arranque definitivo en la historia antillana para superar, de una vez y por todas, la colonialidad del poder en sus manifestaciones más perniciosas y perversas.

\section{LA «ISLA-ESTADO», O EL TRIUNFO DEL IMPERATIVO GEOPOLÍTICO DE LA CARTOGRAFÍA COLONIAL}

El imperio «presidencial» impuesto desde Washington contempló siempre a las Antillas como un cinturón sanitario para proteger, en un sentido estratégico-militar que no poco se ha debido también al miedo a la «contaminación racial», lo que todavía algunos ven como el soft underbelly o la zona vulnerable (del «vientre bajo») de Estados Unidos de cara al Golfo de México. La construcción del Canal de Panamá y su inauguración en 1914 hizo de ese cinturón un arco de acero con sendos remaches en la base naval de Guantánamo y los importantes campamentos, centros de entrenamiento y bases de

\footnotetext{
9 Sobre esto he escrito antes y de forma provocadora en Buscaglia Salgado, 2011.
} 
ataque en Puerto Rico. Ahora las Antillas no solo protegían el vientre bajo de Usonia sino que aseguraban la integración interoceánica del país, uniendo por vía marítima Nueva York con San Francisco. Como sucedió en la factoría esclavista de los hermanos Colón a finales del siglo XV cuando La Española vino a nombrar por primera vez lo que hasta hoy muchos ponen en duda, es decir, la existencia misma de lo español como sinónimo del conjunto de los pueblos de toda la Península Ibérica, las islas se abrieron para que el tajo por Panamá hiciera de Estados Unidos un imperio continental bien asegurado. Una vez más las Antillas servían para promover la felicidad de otros pueblos lejanos a costa y en contra de los mejores intereses de la inmensa mayoría de los isleños. Así, dada su estratégica ubicación, Puerto Rico se convertiría ya entrado el siglo en una plataforma de sumo valor estratégico para proyectar el poderío naval y nuclear de Estados Unidos en el Atlántico Norte y Cuba acabaría al borde del suicidio colectivo durante la Crisis de Octubre de 1962.

Amparándose en la Doctrina Monroe, la «Pax Usoniana» se impuso de forma sistemática y concertada comenzando con la guerra contra España en 1898, seguida del apoyo naval y diplomático a la escisión de la entonces provincia colombiana de Panamá (1903) y las diversas invasiones y ocupaciones militares de Haití (1914-34) y la República Dominicana (1916-24). La nueva potencia hemisférica respetaría la jurisdicción de las potencias europeas en las Antillas Menores guardando estrictamente, tanto en éstas como en las Mayores, los viejos protocolos coloniales para mantener intactas las fronteras y apoyar el continuo saqueo de las dependencias administrado desde las ciudades de cabecera de las antiguas colonias. De hecho, el Congreso usoniano se guió fielmente por los protocolos británicos para establecer el orden colonial en Puerto Rico bajo la Ley Foraker de 1900 que hizo del país el mercado cautivo que sigue siendo.

El nuevo arreglo corrió a contrapelo de lo que había sido el proyecto antillanista. En vez de la integración desde la soberanía popular se fomentó estrictamente la separación en función de un sistema organizativo basado en el problemático concepto de la isla-estado. A diferencia de la ciudad-estado o, incluso, de la nación-estado, la isla-estado antillana es un artefacto que responde principalmente a un imperativo geográfico y colonial que dista mucho de un modelo político viable de ciudadanía y soberanía. Esto es lo que entiendo como las patrias chicas, es decir, aquellos estados débiles pero bien apuntalados desde afuera donde en términos conceptuales y programáticos se ha venido confundiendo siempre a la isla con la nación. Estos estados malformes, que no son otra cosa que contenedores de conveniencia, han respondido invariablemente a los intereses de unas élites criollas mayormente subordinadas a Washington, y en menor escala a París, Londres, Ámsterdam e incluso Moscú. 
A lo largo del siglo XX y corriendo por todo el arco de las islas, desde Cuba hasta la Trinidad y tan allende el mar como las Islas Bermudas, estos pequeños feudos criollos han sido los custodios de la colonia en la república, hayan sido o sean éstas naciones soberanas o neocolonias del imperio de turno. El impulso avasallador usoniano y la pesada carga de la colonialidad han sentado las pautas de un desarrollo atrofiante en aquellos países donde los regímenes neocoloniales se dieron por transición pacífica aunque no menos violenta, como en el caso de Puerto Rico o la Martinica. En aquellos cacicazgos postcoloniales como la Haití de Dessalines, de Henri Christophe y los Duvalier, la República Dominicana de Santana, Ulises Heureaux y Rafael Leónidas Trujillo, o la Cuba de Céspedes, Fulgencio Batista y los hermanos Castro Ruz, donde el racismo de siempre y la plantación renovada, amén de la independencia patria sin amplias libertades ciudadanas, dieron pie a la pesadilla del pequeño imperio insular, el desarrollo no ha sido otra cosa que trágico en la medida en que la independencia ha servido para continuar y recrudecer el reino del terror heredado de la herencia colombina y la plantación esclavista.

En este sentido encuentro solo matices entre caciques liberales y sosegados como Aimé Césaire, Luis Muñoz Marín o incluso Eric Williams, y caudillos implacables y delirantes como Trujillo, François Duvalier y Fidel Castro. Véanse como defensores sanguinarios y a ultranza de la patria chica y de «la raza» nacional, o como muy cuestionables modelos de virtudes democráticas en la colonia, todos ellos han sido figuras problemáticas desde una perspectiva antillanista integradora. Y es que todos ellos, indistintamente de sus preferencias ideológicas, acabaron plantando bandera para regir desde las viejas capitanías generales, como gobernadores de turno o vitalicios, en defensa de la supuesta inviolabilidad de unas fronteras que fueron fijadas hace siglos por tratados entre príncipes europeos y que en la práctica nunca fueron respetadas por los pueblos de la región dedicados en su inmensa mayoría, desde 1492, al contrabando y a la burla permanente de toda jurisdicción que pretendiera reducirlos a un régimen insular de corte colonial o presidiario.

Hoy, el fin de la Doctrina Monroe llega por desgaste y agotamiento imperial cediendo el turno a nuevas fuerzas pujantes que son imperios en derecho como la República Popular China o en gestación como los narco estados emergentes en la zona. Todos estos intereses contemplan el Caribe como un punto de paso que debe controlarse y explotarse a toda costa. Quedamos pues como empezamos la modernidad temprana y colonial, rindiendo pleitesía a la lógica de la fragmentación mientras otros codician las vías marítimas que cruzan de un lado al otro el Mar de las Antillas. Muy a pesar de ser nuestra principal fuente de riqueza potencial, será imposible reclamar jurisdicción sobre esas aguas, que de antillano solamente llevan el nombre, mientras las islas-estado 
sigan oficialmente dándole la espalda al mar en un desparramamiento político que es una sangría sin fin. En un mundo donde el poder se ejerce desde los grandes cantones, la incapacidad de asumir una postura estratégica única y consensuada a nivel regional es malbaratar toda herencia y hacienda. Como tal los antillanos viven a nivel colectivo, pueblo por pueblo, lo que en el Caribe hispanohablante se conoce como un "sal pa' fuera», es decir, una condición nada deseable que supone la pérdida total de injerencia y de control.

El sentido de ese muy antillano «sal pa' fuera» dentro del contexto de la isla-estado es movimiento sincrónico y siempre en tándem con el «sálvese quien pueda». Sin embargo, la falta de empatía a nivel colectivo regional supone que en este naufragio cada pueblo se ahogará en solitario, isla por isla. Este es el contrasentido de un «sal pa' fuera» sin salida aparente y de un sálvese quien pueda donde todos permanecen a bordo y se hunden con la embarcación. Aquí los pueblos de las islas-estado comparten a nivel del discurso oficial una cultura de cabotaje que les obliga a navegar a vuelta redonda y muy ceñidos de la costa advirtiendo siempre del gran peligro a aventurarse más allá del horizonte y acabar entre los «salvajes» de la isla vecina.

Para entender esta aparente contradicción hay que saber que, lejos de la visión integradora de la Liga Antillana y de la tradición ancestral de la fuga y del contrabando, el Caribe es hoy materia mucho más cabal en la propaganda comercial y turística que en las mentes y el sentir de los antillanos mismos. Mientras el mundo sigue ubicando a las Indias Occidentales en las playas de cocoteros llenas de mulatas y mulatos complacientes con sabor a piña colada allí donde una isla da igual que la otra, los isleños se aferran a una idea de «la isla bonita» que hace único a su terruño y que, buscando competir por la atención del extranjero tronca cualquier posibilidad de entablar una visión coherente del entorno regional. Como si fuere todo un concurso de belleza, cada isla bonita se disputa el honor y el horror de haber sido la tierra que Cristóbal Colón describiera como la más bella que ojos humanos vieran.

En este sentido la isla que se repite y que se ha venido repitiendo desde 1492 no es la Cuba de Antonio Benítez Rojo ${ }^{10}$ sino las Insulae Americanae, o «islas americanas», del maestro cartógrafo Joan Blaeu. Sobre ese mapa tan conocido y reproducido se ha trazado desde el siglo XVII la ruta de regreso a una suerte de paraíso perdido donde cualquier don nadie europeo o eurodescendiente puede aspirar a hacerse gente. En ese cuaderno de bitácora que invita a la fantasía de ser dueño y señor de un trozo del mundo, las islas de las Antillas parecen frutos de una cornucopia que desde el Seno Mexicano se desborda para verter sus frutos sobre el Mar del Norte. Allí están todas

\footnotetext{
${ }^{10}$ Benítez Rojo, 2010.
} 
al alcance de la mano como en cualquier resort turístico de Cuba, Jamaica, Haití o la República Dominicana donde la prostitución es ley: tome usted la que más le guste y haga con ella lo que desee. La isla del tesoro es hoy la fantasía de todos y para todos salvo para los isleños. Hacia ese «destino secreto» se desplazan desde los que apenas alcanzan a escaparse por un fin de semana junto con Mickey Mouse en el crucero de Disney que zarpa desde Miami, hasta los que logran llevarse el botín entero para hacerse de su propio paraíso terrenal en las islas palmeras de Palm Jumeirah y Palm Jebel Ali en Dubai. Mientras tanto los cubanos, haitianos y dominicanos se lanzan al mar prefiriendo nadar entre los tiburones que vivir en las islas dolorosas en las que nacieron.

LA «ISLA-PRESIDIO», O EL «INSULARISMO» POR BANDERA DE LA «ISLA-ESTADO»

La contraparte americana de ese impulso prostibulario, en un principio europeo, luego usoniano y ahora universal, de poseer una isla en el «paraíso de la plantación» en las Indias Occidentales es una condición psicosocial caracterizada por un sentido de inadecuación y una vocación al auto-rechazo que se conoce vagamente como el «insularismo» ${ }^{11}$. Siendo la esencia del ser y del quehacer isleño, el insularismo es la espina que vertebra la espalda, en este sentido corva, del homo antillanus. Como bien ha indicado Tony Thorndike, «todo el engranaje del sistema colonial no solo toleró el insularismo sino que lo promovió activamente» ${ }^{12}$. Las independencias, allí donde se dieron forzosamente o se impusieron por real decreto, y los innumerables regímenes autonómicos y neocoloniales que surgieron en la posguerra, han hecho indistintamente del insularismo el más distintivo estandarte de la isla-estado.

Por un lado, el insularismo se desborda en el orgullo desmedido de la isla bonita: nada es mejor, más grande o más bello que en mi isla. Los cubanos, entre ellos, suelen bromear al aceptar que, por ser una isla en el Caribe (aunque no necesariamente caribeña), Cuba no se puede comparar con grandes países continentales como Estados Unidos o la antigua Unión Soviética. En cambio dicen que, para ser justos, es mucho más acertado compararla con Inglaterra, Japón y Australia (que no con cualquiera otra isla, cayo o islote en las Antillas, África o Asia). La broma termina cuando hacemos un registro del discurso oficial para verificar que Cuba ya no es una isla sino que su actual gobierno

\footnotetext{
${ }^{11}$ Ver, por ejemplo, el muy problemático tratado racialista de 1934 precisamente titulado Insularismo. Pedreira, 2001.

12 Thorndike, 1991: 125.
} 
la define como un archipiélago que incluye la Isla de la Juventud (Isla de Pinos) y unos mil seiscientos cayos e islotes. Pero ¿cómo puede haber un archipiélago dentro de otro? ¿O será acaso que aquello que Antonio José Ponte llamó el imperio cubano, y que ahora incluye partes de la Venezuela chavista, ya no cabe o quiere caber dentro de las Indias Occidentales ${ }^{13}$ ?

Por otro lado el sentido profundo de inadecuación al cual responde el insularismo se manifiesta en una mímesis exagerada y no poco burlesca de todo objeto, gesto cultural o producto intelectual proveniente de un «fuera de la isla» que todo lo abarca y cuyas glorias se vuelcan sobre los isleños en una relación inversamente proporcional que los achica mientras ellas se levantan sobre el horizonte como velas de gavia bien ceñidas al palo mayor. Algunas veces este tipo de posicionamiento alcanza expresiones nítidas como en el caso de una versión «alternativa» del himno nacional que es popular entre los niños puertorriqueños. Ya en 1952 para lanzar la relación neocolonial del Estado Libre Asociado o Commonwealth of Puerto Rico, los ideólogos y censores del régimen habían transformado la letra de «La Borinqueña», escrita al comienzo de la Guerra de Independencia en 1868 por Lola Rodríguez Tió, la poeta y defensora de los derechos de la mujer que fue una antillanista destacada. Queriendo borrar el carácter bélico de la letra original del himno, la estrofa que leía «Nosotros queremos la libertad y nuestros machetes nos la darán» fue trocada por: «Cuando a sus playas llegó Colón exclamó lleno de admiración». Al margen de esta manipulación desde la sala de máquinas de la ideología oficial, los niños de primaria se ríen del Gran Almirante y se mofan sin saberlo de los oficiales responsables, de ellos mismos y de su propio pueblo pintando a su isla-estado como el retrete del llamado descubrimiento y de la modernidad colonial en su momento fundacional: «Cuando a sus playas llegó Colón alzó la pata y tiró un mojón». Esta postura antiheroica no solamente apunta a la poca valía que se le puede llegar a otorgar al terruño patrio sino que es también reflejo de un rechazo popular y generalizado de toda solución nacionalista a la condición colonial. No obstante, este gesto aparentemente cargado de gran autodesprecio es también una condena de la gesta misma a la cual se alude, es decir del llamado descubrimiento y de toda la historia de Europa en el Nuevo Mundo. Según lo pintan los niños boricuas en sus juegos de recreo, Colón fue quien desde un principio lo echó todo a perder.

Este sentimiento de inadecuación tan propio del sentir insularista responde a un saberse atrapado dentro de una isla que ha hecho las veces de encomienda y barracón, burdel y resort, y que hoy conjuga todas esas suertes en la cárcel

${ }^{13}$ Ponte, 2002. 
del imaginanio colectivo. Ese presidio interno que apoca toda posibilidad de ser y del saberse antillano ya no responde al régimen de la antigua colonia penal sino a la realidad de vivir aparentemente sujetos, como pena a perpetuidad, a los órdenes arquitectónicos que sostienen la colonialidad en el poder. Esa es la isla-presidio que se cierne sobre sus gentes como una gran quimera allí donde la colonialidad y la cultura son una misma cosa. En este sentido se podrá enajenar al isleño de la isla pero es difícil contemplar la posibilidad de sacar a la isla del isleño, máxime cuando esa condición viene protegida por un poderosísimo resguardo. $Y$ es que el insularismo se manifiesta en el cuadro depresivo y autodestructivo de la autoconmiseración que exime al isleño de toda culpa y obligación respecto a su condición servil y miserable. Allí es donde Virgilio Peiñera buscó sin éxito hacer zozobrar a «La isla en peso» ${ }^{14}$ bajo la carga de amor que su pueblo le profesa. Ese gesto recoge toda la frustración existencial de José Martí en su "Odio el mar" ${ }^{15}$ y resume el sentido trágico de la isla como trampa en Aimé Césaire cuando se refería a «Lo que es mío, estos cuantos miles de moribundos, ganapanes de la muerte que giran en corro dentro de la calabaza de una isla» ${ }^{16}$.

Al final, ese mismísimo sentimiento de hallarse encajonado sin posibilidad de salida desemboca en un deseo de volver atrás para empezar de nuevo e intentar acceder así a una modernidad no colonial. Ese es el instinto que aflora entre los niños de Puerto Rico antes de ser arrancado de raíz por la buena educación colonial. Esta visión de arrancarse la quimera y enfrentarse a la impotencia regresando más allá del origen poco edénico del «levantamiento de pata» colombino fue ya claramente enunciada por el poeta puertorriqueño Virgilio Dávila en el estreno mismo de la «Pax Usoniana» en 1898:

Queden, patria, si es tu sino,
difamados tus varones;
tu albo manto hecho jirones
en las zarzas del camino.
¡Y caiga el rayo divino
sobre el déspota triunfante!
¡Y sea maldito el instante
en que te vio, entre ola y ola,
el sabio marino, sola
en medio del Mar Atlante ${ }^{17}$ !

14 Piñera, 2006.

15 Martí, 2002: 66.

16 Césaire, 2008: 45.

17 Dávila, 1964: 26. 
Quizás el insularismo antillano no diste mucho de las contradicciones y contrasentidos de otros pueblos que han sufrido la colonización o el vasallaje y que han sido igual de trágicamente incautos al intentar abrirse paso hacia la felicidad que otras gentes parecieran disfrutar. Sin embargo, la herencia de la colonialidad en el poder se suma a la ideología y al sentir insularista en una mezcla tóxica. La primera al racializarnos evita que nos entendamos como pueblos con un interés común dentro de la isla-estado. La segunda nos condena a la isla-presidio sin posibilidad de hacer causa común con los vecinos del otro lado de la frontera terrestre o marítima. Es claro que el ultranacionalismo en las islas siempre ha respondido al interés de frenar los reclamos populares para restaurar por la fuerza un orden que obligatoriamente nos refiere a las prácticas de control y represión de la colonia y su plantación. Ahí está para probarlo el mentado catalogo de reinos del terror regidos por el insularismo racialista, desde Dessalines a los Castro Ruz.

Pero en el plano de las ideas y de los proyectos políticos más alucinantes el insularismo requinta en un sentimiento de incompetencia harto exagerado que busca consuelo fácil en la dependencia extrema a una potencia foránea. La isla a la deriva busca dejar atrás el archipiélago para luego lanzar cabos a todo lo que se asemeje a tierra firme. Tómese como ejemplo más reciente el caso del Movimiento de Reunificación con España (MRE). Este incipiente proyecto surge en Puerto Rico como respuesta a un plebiscito propuesto por el Congreso usoniano a principios de 2014 con el objetivo de clausurar y demoler el inmueble colonial más antiguo de la historia moderna. Los líderes del MRE, que alegan contar con el apoyo del 20 por ciento del electorado, buscan frenar el avance del sector que aboga por la incorporación del país como estado federado de Usonia defendiendo la opción algo curiosa de reclamar a la España de hoy los derechos otorgados por la corona a los puertorriqueños en la Carta Autonómica de 1897.

La idea de hacer de Puerto Rico una región autonómica de un país que aún tiene dependencias neocoloniales en África y donde el modelo autonómico está siendo socavado por procesos de renovación constitucional bajo presión de movimientos independentistas en Cataluña y el País Vasco resulta un tanto incongruente y bastante desatinada cuando no de plano absurda e imposible. Además eso ya lo intentó Pedro Santana a mediados del siglo pasado con la España de Isabel II, desastre que provocó la Guerra de Restauración de la República Dominicana y el auge de la doctrina pan-antillanista. Por eso hay que entender la propuesta del MRE como reflejo concreto de un sentido de incompetencia e insuficiencia generalizado en el país respecto a la capacidad de las élites locales para hacerse cargo sin apoyo político-militar ultramarino de mantener el orden racialista en casa de «la gran familia puertorriqueña». En 
ese sentido el MRE y su propuesta distópica vienen a poner en evidencia el propio desatino del proyecto federalista de los boricuas que se piensan «protousonianos» y que carecen igualmente de confianza en sí mismos al dudar de su capacidad para montar y mantener un gobierno propio y soberano aunque no popular. No obstante, lo más curioso del caso es que el principal portavoz del MRE y su reclamo de volver hacia atrás para regresar a la «monarquía con democracia» pidiendo la anexión a España era, hasta fechas recientes, el líder máximo del Partido Nacionalista de Puerto Rico, colectividad política de corte militarista, ultra católico e hispanófilo y, en todo otro sentido, fascista $\mathrm{y}$, por ende, esencialmente antimonárquico y antidemocrático.

No es de extrañar pues que esta extraña coincidencia del deseo de regresar a un pasado precolombino sin pecado original con la visión de salida a toda costa hacia un destino ultramarino imposible por inexistente, sea no solo el resultado de la ruptura generada por la «Pax Usoniana» imperante durante todo el siglo pasado sino también la manifestación más clara de una herencia que se esconde tras el insularismo como la tradición más arraigada y nociva en la cultura insular. Me refiero al repudio de la circunstancia inmediata que encuentra su manifestación más extrema en el odio al entorno y más específicamente hacia el vecino. En algunos casos, como en la Española, Cuba o San Cristóbal, un deseo de cortar por lo sano divide a la isla en dos partidos o pueblos supuestamente antagónicos. No es raro, aún hoy en día, escuchar en cualquier lugar de la isla de Cuba al oeste de Camagüey la expresión «en Oriente ni los perros ni la gente». Así es de uso común entre los cubanos de «occidente», pensándose más «blancos»y dignos de su gentilicio, llamar con el mote despectivo de «palestinos» a los cubanos «orientales» haciendo de los habaneros una suerte de judíos o pueblo escogido de dios en las Antillas.

Quizás no haya prueba más contundente de esta aberración nacida del miedo profundo a reconocerse en el «otro» que el reciente fallo del Tribunal Constitucional de la República Dominicana del 23 de septiembre de 2013 que niega la nacionalidad a los hijos de padres extranjeros en situación migratoria irregular nacidos a partir de 1929. La medida ha convertido a más de medio millón de dominicanos de procedencia haitiana $-\mathrm{y}$ a otros solamente por ser «negros», indigentes y sin papeles- en apátridas. Curiosamente el odio a todo lo haitiano en la dominicana se desgaja de la división histórica en Haití entre el partido de los «negros» y el de los «mulatos», que ha hecho al país prácticamente ingobernable desde 1804 y que es la manifestación más antigua aún vigente del insularismo en su vertiente «intra-xenofóbica». Esta terrible herencia ha sido promovida directa e indirectamente por los estados insulares y sus patrias chicas dentro del marco de la «Pax Usoniana» hasta el punto en que es hoy casi imposible proponer una visión estable y constructiva de un ser 
o de un sentir regional. ¿Y cómo no va a ser así si, por definición, el insularismo racialista nos encamina hacia la autodestrucción genocida remitiéndonos al ejercicio del suicidio colectivo que fue la última iniciativa organizada de los cacicazgos arauacos ante el poder militar devastador empleado por los cristianos europeos contra la rebelión de 1511?

\section{EL TERROR RACIALISTA SE NUTRE DEL MIEDO A «NOS-OTROS» MISMOS}

¿De dónde proviene el odio y el desprecio que sentimos unos contra otros y que es tan contrario a los ideales que animaron el proyecto confederativo hace ya más de un siglo? No hay lugar aquí para contestar esta pregunta a fondo. Pero cabe recalcar que la historia del racismo, y del racialismo como historia, corre en paralelo con la evolución social, política e intelectual de los pueblos antillanos. En este sentido, el desprecio que mostramos por nosotros mismos, o por aquellos «otros» de entre nos, es en gran medida el mismísimo reflejo del oprobio que nuestros ancestros sufrieron a manos de los antiguos amos de quienes somos también, nos guste o no admitirlo, retrato fiel en el álbum de familia de la colonialidad del poder.

Baste por muestra contrastar la facilidad con la cual se rechaza a un paisano, o al ciudadano del otro lado de la frontera o de la isla vecina, con la actitud servil que se suele asumir frente a un turista usoniano o europeo. Esta postura no está limitada a los territorios que continúan siendo colonias. Se da en todas partes e incluso, también, en la Cuba «revolucionaria» donde el discurso oficial siempre ha promovido una falsa división entre el pueblo usoniano y su gobierno. Si aquello es una república donde los ciudadanos elijen abiertamente a sus líderes entonces no hay separación posible entre el pueblo y el gobierno usonianos. Por tanto, la cortesía desmedida con la que se regala en Cuba a los mal llamados yanquis, sobre todo comparándose con lo que se puede oír decir de un jamaiquino o de un haitiano, o de un cubano santiaguero por el mero hecho de ser considerados «negros» en ciertos vecindarios de La Habana, es un remanente de la colonialidad que sigue siendo cultura viva en su profesión de fe al insularismo más arraigado y racista.

Ni hablar de las pruebas más fehacientes de la violencia que implica actuar como «blanco» por no querer ser «negro» y que, contrario a la retórica nacionalista, descubre en los isleños al descendiente directo del amo colonial. El fallo del Tribunal Constitucional de la República Dominicana del 23 de septiembre de 2013 no fue un acto político o legal sin precedentes sino un paso coherente en el marco de la historia de la colonialidad del poder en La Española. El gobierno dominicano ha recibido duras críticas de organismos 
internacionales y de sus propios ciudadanos. Pero también ha disfrutado del respaldo incondicional de los vocales defensores de la herencia más terrorífica del insularismo racialista. En la madrugada del 4 de febrero de 2015 apareció colgado de un árbol en el Parque Ercilia Pepín en Santiago de los Caballeros, República Dominicana, el cuerpo sin vida del ciudadano haitiano Claude Jean Harri, alias Tulile, un joven limpiabotas, casado y padre de dos hijos. La noche anterior miebros del «Movimiento Patriótico, RD Libre e Independiente» habían quemado una bandera haitiana en el Parque León Jiménez. Este movimiento aboga por la expulsión de todos los «negros» de la República Dominicana y por la construcción de un muro de contensión racial en la frontera con Haití.

Por esto insisto en que las Antillas son las amas de llave de ese discurso que tanto nos gusta a los americanos denunciar como «cosa de blancos» o de europeos pero que, a decir verdad, es la más temible creación de nuestra civilización criolla. Me refiero, claro está, al racialismo y a todos los prejuicios religiosos, políticos, geográficos y lingüísticos que abonan y hacen crecer a ese formidable engendro ideológico sin par en el mundo moderno. En las islas afrohispánicas hay gente dispuesta a negar a sus progenitores por pensarse «blancos» y hay muchos que en las anglófonas, creyéndose «negros» a la inglesa, es decir sin «mancha»o «contaminación racial», miran a los vecinos que hablan otras lenguas o pueden parecer de «raza mixta» pensándose más étnicamente puros que Isabel de Windsor quien, a estas alturas, sigue siendo reina de Jamaica, Barbados, las Islas Bahamas, las Bermudas y Granada al tiempo que su familia figura entre los principales beneficiarios de la trata esclavista en toda su larga historia.

Isabel es un símbolo vivo de la colonialidad del poder. En eso es tan antillana como cualquier isleña. Pero, como reina de una isla rica y distante de las tierras donde la descendencia de sus antiguas dotaciones se desangra diariamente en luchas callejeras por intentar cumplir con el lema impuesto con la independencia forzada «de muchas (razas), un solo pueblo» ${ }^{18}$, todavía se puede dar el lujo de desentenderse y evadir toda responsabilidad al respecto. No será por mucho más tiempo pues el proceso legal de reclamar compensación por los daños y perjuicios de la trata esclavista y el genocidio de la población originaria de las islas, lo que en inglés se conoce como reparations, ya ha comenzado ${ }^{19}$. Ese juicio debiera venir acompañado de un acto de contrición en paralelo mediante el cual los isleños aceptáramos de una vez y por siempre, a nivel individual y colectivo, que en las Antillas no puede continuar entronizado el reino del terror de la pureza de sangre pues todos somos de todo.

\footnotetext{
18 Tomado del escudo de armas de Jamaica: "Out of Many, One People".

${ }^{19}$ Ver el formidable alegato en el reciente tratado de Beckles, 2013.
} 
Mientras tanto y como casi siempre, los encargados de mantener el orden de la colonialidad en el las Antillas seguirán siendo los antillanos mismos. Hay muchos cubanos que recuerdan, aunque no se atrevan todavía a enunciarlo y mucho menos a denunciarlo, cómo fue que el General de División Arnaldo Ochoa Sánchez perdió los galones y el honor de ser Héroe de la República de Cuba antes de ser fusilado el 13 de julio de 1989. Acusado de enriquecimiento ilícito en el tráfico de drogas, armas, diamantes y divisa, el fusilamiento de Ochoa fue precedido por un artificioso auto de fe televisado. Quienes conocen bien el aparato represivo de ese pequeño imperio insular saben que lo que hizo de ilegal el general tuvo que haber sido sancionado por el Líder Máximo. Lo que le condujo al paredón fueron razones de otro tipo. Vislumbrando ya el desmembramiento de la Unión Soviética y el Pacto de Varsovia, Fidel Castro condujo aquella purga como un gran escarmiento para todo el pueblo cubano. Detrás de todo el tinglado complejo de la sangrienta ópera bufa que fue el caso Ochoa la selección del general como chivo expiatorio no fue nada arbitraria. A su regreso de la guerra en Angola Ochoa había desatado la ira del Comandante en Jefe proponiéndole reunir bajo un mando unificado los dos ejércitos de la Fuerzas Armadas Revolucionarias de Cuba: el Oriental y el Occidental ${ }^{20}$.

En otras palabras, Ochoa había propuesto derribar el muro que separa a los palestinos del «lejano oriente» cubano de los «judíos» de una Habana «jerosolimitana» que son y han sido siempre el pueblo escogido de Cuba. Esta es la división militar e histórico-racialista sobre la cual se ha balanceado muy precariamente la idea de esa isla-presidio. Quienes en las Antillas han sabido ejercer el control mediante la represión más sofisticada, y de entre ellos nadie más eficazmente que los hermanos Castro Ruz, han sabido siempre que el balance depende de encontrar la mezcla precisa entre el «terror del blanco» y el «miedo al negro».

En la historia de los estados antillanos bajo la «Pax Usoniana» los ejércitos han tenido una función exclusivamente policial y represiva respecto al orden político racialista. En este sentido el caso cubano vuelve a ser quizás el más destacado, seguido de cerca por el dominicano y el haitiano. Aún cuando se toma en consideración la postura oficial numantina del gobierno de aquel país de defender la patria contra un siempre inminente «ataque imperialista» (que no ha sido nada probable al menos desde 1976 y no volverá a serlo nunca) resulta injustificable mantener dos ejércitos (en realidad serían cuatro si se tomaran en cuenta las viejas Milicias de Tropas Territoriales y el omnipresente Ministerio del Interior) en un país tan pobre y pequeño como Cuba amén de que sea ilógico, por definición, que un estado insular requiera de un ejército de tierra.

\footnotetext{
20 Fuentes, 1999.
} 
Por eso la razón de este aparente sinsentido reside en mantener vivo el miedo al otro de entre nos que nutre el odio en el imaginario colectivo que desde el principio de la colonia ha dividido a Cuba en dos. Esta es una zanja que durante la Guerra de Independencia fue trocha fortificada por las fuerzas coloniales españolas y que hoy, según el discurso oficial de la «Revolución», solo puede salvar, en nombre de la «Patria» martiana como fuente indiscutible de la identidad única, el culto a la muerte en la inmolación colectiva que viste la figura del Comandante en Jefe y la larga lista de víctimas ocultas bajo su manto verde olivo. La popularidad de Ochoa entre los hombres y mujeres que comandó en Angola empezaba a incomodar al Líder Máximo. Súmese a esto que el reclamo de poder del general al cuestionar la división del país en dos partidos era inseparable del hecho que los cubanos destinados a Angola fueron en representación desproporcionada «negros», «mulatos»y «palestinos».

«PETIT PAYS, PETIT PETIT» ${ }^{21}$, O LA ILUSIÓN DE LA SALIDA ÚNICA

Irónicamente el odio al vecino nos hace un solo pueblo porque lo sentimos todos a la vez y lo ejercemos todos contra todos. Bien sabemos los hijos de las Antillas que el racialismo es un sistema ideológico que se fortalece mutando con cada nueva mención directa o indirecta de órdenes que son, en última instancia, genocidas. A pesar de esas grandes dudas lo practicamos religiosamente. De ahí que por evitar entenderse con el vecino, estos pequeños pueblos insulares vivan dándole la espalda al mar que les rodea mientras dejan abiertas las compuertas para que los emporios del mundo muevan libremente sus mercaderías por la zona. Al final el insularismo racialista es la impronta más profunda hecha por la herencia colonial y las prioridades imperiales de siempre sobre la cultura y el imaginario colectivo de los pueblos antillanos. Por más alboroto que hagamos, ese legado que es cultura viva nos hace países pequeños sujetos a líderes grandes pero nunca a grandes líderes con apoyos e ideas de escala regional.

Los partidarios del proyecto confederativo antillanista fueron conscientes de esta limitación y la combatieron activamente bajo el lema de «las Antillas para los hijos de las Antillas» acuñado por el abolicionista y republicano puertorriqueño Ramón Emeterio Betances ${ }^{22}$. Esa filosofía política que cobró forma

${ }^{21}$ Evora, 1994.

${ }^{22}$ Ramón Emeterio Betances Alacán (1827-1898) fue líder de la Insurrección de Lares (Puerto Rico, 1868), colaborador cercano del general dominicano Gregorio Luperón y, entre otros cargos, ocupó la representación en Europa del Partido Revolucionario Cubano (18951898). 
en la Guerra de la Restauración de la República Dominicana fue combatida enérgicamente por Ulisses Grant, el primer presidente imperial usoniano en fijar las Antillas como objetivo estratégico de máximo interés. Para Grant era urgente evitar que surgieran en el Caribe lo que él y los suyos veían como repúblicas de «gente problemática de todas las naciones» ${ }^{23}$. Entiéndase por ello, personas «no blancas» en índole y procedencia. Con la «Doctrina Grant», hija de la Monroe, Estados Unidos se propuso quebrantar a las Antillas Mayores una por una antes de quedárselas todas. El viejo general que aplastó la Guerra de Secesión no estaba dispuesto a ver surgir otra confederación sureña y menos tratándose de lo que el veía como una conspiración de «negros» de vocación antillanista contrarios a la expansión incondicional del poderío usoniano. De ahí su repetida intromisión en el conflicto dominicano y su plan de tomar la bahía de Samaná y su península, asegurando así la fractura a perpetuidad de un proyecto político soberanista en la isla que ha servido siempre, desde tiempos precolombinos, como nervio vertebrador de todo el archipiélago.

La guerra contra España en 1898 vendría a terminar esa faena reforzando las antiguas fronteras coloniales bajo una nueva administración que alimentaría con buen pienso al engendro del insularismo racialista. Al violentar el impulso que animaba a los confederados antillanos la influencia desmedida de Washington obligaría a cada uno de los países donde se había gestado la idea, empezando por Cuba, a claudicar por separado. Piénsese, por ejemplo, en la Enmienda Platt de 1901, el proyecto de «americanización» en Puerto Rico, y en las repetidas invasiones y ocupaciones usonianas de Haití (1891, 1914-1934, 1994-1995, 2004) y Santo Domingo (1903-1904, 1914, 19161924, 1965-1966).

La diplomacia armada usoniana siempre estuvo presta a imponer cabecillas de estados dependientes, como en el caso de Trujillo y su heredero Joaquín Balaguer, y a acudir al rescate de élites bajo acoso de las masas como ocurrió en Cuba con la masacre de los abanderados del Partido Independiente de Color en 1912 o en la Granada del New Jewel Movement en $1983^{24}$. Todo esto ha contribuido a reforzar la idea de la diferencia, heredada de la colonia y propulsada por el insularismo racialista, de que las Antillas presentan un panorama humano incongruente e infinitamente diverso que, por conveniencia administrativa y para hacer buen uso de la policía depende para su control y funcionamiento óptimo del acantonamiento de tropas que circunscriban estrictamente a sus gentes dentro de sus respectivas islas, cayos e islotes.

\footnotetext{
${ }^{23}$ Keim, 1870: 94-95.

${ }^{24}$ Para más información sobre los independientes de color ver Helg, 1995.
} 
Por eso las independencias, allí donde se dieron, no han logrado superar la herencia colonial. En todo caso han servido para reforzar las supuestas diferencias irreconciliables entre los pueblos de la zona y los intereses en común que pueden tener estos por separado con los imperios ultramarinos de ayer y de hoy. El ejemplo clásico de esto fue la corta duración de la West Indies Federation o Federación de las Indias Occidentales (1958-62) y el rápido regreso de las viejas posesiones inglesas a la unidad básica de la isla-estado heredada de la colonia. Por esto no existe hoy en el mundo otro lugar donde las fronteras coloniales coincidan tan precisamente con las de los estados soberanos postcoloniales y las extrañas dependencias neocoloniales. En otras palabras, no hay otro lugar donde la independencia como proyecto político haya sido tan efímero por más vidas que pueda haber costado.

Al final, como el propio caso de Cuba hace sobradamente evidente, la independencia como ideal nunca logró reconciliarse con la libertad en términos concretos. La República de Cuba se proclamó izando la monoestrellada sobre el Castillo del Morro de la Habana en 1902. La decisión de celebrar el acto en una fortaleza militar que era el símbolo más representativo de la represión colonial vino a confirmar que el país estaba condenado desde el Grito de Yara en 1868, si no desde mucho antes, a ser una tierra de militares y de sus víctimas. En las Antillas, en vez de derrumbar nuestras Bastillas las hemos convertido en altares de la patria cuando no, como en el caso absurdo de Puerto Rico, en el ícono de la Compañía de Turismo que toma como símbolo del país las garitas que se levantan sobre las murallas de San Juan y desde donde los centinelas se mantenían alertas ante la amenaza constante de enemigos externos y de los desafectos al régimen de intramuros.

Cuba es sin duda el ejemplo más trágico de lo que llamo la ilusión de la salida única, es decir, la idea de que las libertades ansiadas pueden hacerse patentes y ser aseguradas mediante la creación de gobiernos insulares que hacen las veces de estados nacionales. Proyectos cerrados aunque permanentemente inconclusos como estos, que a más de un siglo de luchas, sacrificios y dura represión insisten en colocar a los pueblos de rodillas frente al ídolo de la identidad fija y unitaria, responden a una lógica retrógrada y contraria al ideal libertario que supuestamente impulsan. Es claro, por más antiyanqui que se pinte, que la ilusión de la salida única se desprende directamente de la lógica de la colonialidad y responde fielmente a las estrategias de control y reducción auspiciadas bajo la «Pax Usoniana», cuando no a un sentir oculto de querer ser yanqui pensándose incapaz de dar el grado. La obsesión del cubano con lo usoniano no tiene par, pero esto ya es asunto de otro estudio aún inédito.

Por esto muchos pueblos antillanos han rehuido de la independencia, prefiriendo una gestión pobre de sus derechos y posibilidades a la reducción 
arbitraria de las libertades concretas a manos de militares disfrazados de libertadores. Mejor mal acompañados que solos es la idea que resume la lógica de proyectos políticos coloniales y neocoloniales como el mencionado caso en Puerto Rico del Movimiento de Reunificación con España que son también producto de ese deseo de soltar las amarras, zarpar cuanto antes y poner rumbo a tierra distante para dejar atrás a las islas de una vez y para siempre.

Ese sálvese quien pueda de la salida en solitario que en un principio responde al impulso de separarse forzosamente del entorno antillano y caribeño acusa en última instancia una manera ingenua de enfrentarse a la complejidad del mundo y a la espiral eterna del abanico de nuestras posibilidades identitarias. Como bien han aprendido los cubanos a más de medio siglo de castrismo, buscar refugio en la patria chica es condenarse a lo que ellos llaman el insilio, que es el exilio dentro de la isla como comunidad nacional imaginada, es irse a vivir con las cabras como un Crusoe moderno que da orden al mundo desde su islote lejano sin posibilidad alguna de ser rescatado del abandono y el naufragio.

Allí en el archipiélago de Cabo Verde donde las Antillas encuentran su reflejo fiel en mar abierto, Cesárea Évora cantaba una nana melancólica a su pequeño país que encapsula la soledad terrible que supone sentirse aislado del mundo y de la comunidad a la que se debiera pertenecer:
Oi tonte sodade
Sodade sodade
Oi tonte sodade
Sodade sem fim.
(O tanta soledad
Soledad soledad
O tanta soledad
Soledad sin fin) ${ }^{25}$.

DeL “I SHOT THE SHERIFF" ${ }^{26}$ AL «AQUÍ NO HA PASADO NADA» ${ }^{27}$

La otra cara de lo que hoy se llama la cultural currency, o el capital cultural, del insularismo racialista es mucho más volátil. La rigidez de nues-

\footnotetext{
${ }^{25}$ Evora, Cesarea, "Petit Pays", Cesarea, Paris, Medeleine Bastille, RCA 74321254192, 1994.

${ }^{26}$ Marley, Bob \& The Wailers, "I Shot the Sheriff", Burning, Kingston, Tuff Gong, ILPS9256, 1973.

${ }^{27}$ El Gran Combo de Puerto Rico, "Aquí no ha pasado nada”, El Gran Combo en Las Vegas, San Juan, Ochoa Studios, EGC 015, 1978.
} 
tras fronteras históricas, reforzadas como han sido bajo la «Pax Usoniana», contrasta con una cultura de burla y desacato de la ley y de las autoridades que es perfectamente comprensible aunque no del todo justificable por el carácter represivo y el uso arbitrario de las mismas en la colonia y su república. La desconfianza de todo orden establecido que nos inclina preferentemente a actuar, como decimos, «por la libre», produce una parálisis en la acción social conjunta que raya en la desidia. Por eso cuidamos poco lo que podamos reclamar en común, especialmente el ámbito público de la polis y de la política y acusamos gran dejadez en las empresas colectivas. Generalmente toma un huracán, un terremoto o una gran inundación para sacarnos de nuestro asolador desdén. Estamos harto acostumbrados al ruido del desbarajuste anímico y asumimos como inevitable y normal la violencia de las maras y del estado mientras presumimos de formidables. Por eso, como en la política a gran escala, buscamos también la salida individual a los problemas colectivos.

Ese «quítate tú pa' ponerme yo» que informa nuestro proceder, como pueblos y como ciudadanos, atiza una vocación a la violencia profunda y permanente que, fiel a los preceptos del insularismo, dirigimos contra el otro, a costa de la empresa común y el medioambiente. Aquí la experiencia colonial va nuevamente maniatada a la colonialidad, remitiéndonos al pequeño país de la patria chica donde el clan, la ganga, la banda, el partido, o la secta son las únicas estructuras de apoyo frente a un estado fallido y un futuro indecible. Nuestra cultura de la violencia es sistemática y profunda por cuanto es profundamente sistemática. Por eso, aunque a otros les parezca una paradoja, tratamos siempre de evitar la confrontación en el trato personal, entendiendo como de mal gusto la diferencia de opinión y viendo la competencia como afronta, mientras aceptamos con gran resignación todo el ruido y la violencia del sistema. Nada resulta ser mas contrario a los ideales republicanos y al proyecto colectivo y amplio que animaron la causa confederativa antillana. Por eso, al mandamiento que nos obliga a ser todo menos pesados (es decir, violentos por falta de cortesía) hay que añadir la advertencia betancina de que, para hacer comer bien es preciso romper el cascarón de nuestra embriónica vocación antillanista.

De lo contrario quedaremos atrapados en un ciclo vicioso en el cual nuestra burla continua de la ley a nivel individual y como proyecto social amplio es cultura viva que le permite a las autoridades despacharse con los derechos ciudadanos que alegre y rutinariamente claudicamos hasta el punto extremo, vivido en más de un mismo reino antillano del terror, donde una y otra vez un solo hombre se ha hecho con la libertad de todo un pueblo. En esto somos todos machos y «machas» a nivel individual mientras colectivamente queda mucho por desear. Hace poco murió como hombre libre Jean-Claude "Bébé 
Doc" Duvalier. ¿Sabremos algún día cuántos muertos hay a su nombre y todo lo que se llevó de la hacienda?

Bob Marley cantaba con The Wailers en 1973: "I shot the sheriff. But I didn't shoot no deputy". Basado, dicen algunos, en hechos reales lo cierto es que el personaje del alguacil John Brown como símbolo de la autoridad se remonta inevitablemente a la colonia, a la plantación y al dueño de la dotación, es decir al poder ostentado por «los amos blancos». En su actitud de fijar el objetivo en la figura del jefe y no en la de su lugarteniente, Marley y los Wailers asumían un gesto digamos «solidario» que es aparentemente contrario al odio contra ese «Otro» de entre nos que informa el auto-desprecio en el insularismo racialista. Pero ¿quién separa al lugarteniente, como esclavo azotador de esclavos, de su amo y quién dice que el Sherriff John Brown, el mismo que es acusado de "siempre haberme odiado sin motivo alguno» ("Sheriff John Brown always hated me, for what, I don't know") ${ }^{28}$ no es la encarnación misma de esa condición masoquista? De este modo, en menos de tres estrofas se cierra el nudo que ahorca toda posibilidad circunscribiéndonos al ciclo vicioso de la auto-victimización gracias a la cual el tiro disparado contra el alguacil sale por la culata para pegarnos en la cara.

Ese ciclo vicioso es una peregrinación lastimosa en la que pasamos continuamente, sin problema y sin respiro, de caer víctimas de otros a ser nuestros propios victimarios. El sentimiento de inadecuación que heredamos de la colonia y la plantación nos apoca y se manifiesta en la práctica más trágica y generalizada de una auto-conmiseración que nos libra de toda culpa y obligación. No hay mayor pena que la que nos tenemos a nosotros mismos y de ella proviene la frustración que encarna en los exabruptos más iracundos contra todo y cuanto nos rodea. Petit pays, petit petit... cantaba Cesárea Evora pensándose náufraga en un mar cuyo fondo esconde el vasto cementerio de la modernidad colonial y su trata negrera. Con razón le damos la espalda al mar. Pero el miedo a descender a esas profundidades para encontrar la contraparte de nuestro "élan vital" tiene un precio altísimo. La mayor violencia que ejercemos contra nosotros mismos es negarnos la memoria compartida de un gran genocidio del que fuimos tanto artífices como objetivo. Entre nosotros, como en la vieja canción del Gran Combo de Puerto Rico, «aquí no ha pasado nada». Venga la música a sofocar los llantos y los gritos mientras se envainan las cuchillas, se esconde la evidencia y pasamos a pensarnos, nuevamente, los custodios de la más exquisita simpatía.

${ }^{28}$ Marley, Bob \& The Wailers, "I Shot the Sheriff”, Burning, Kingston, Tuff Gong, ILPS9256, 1973. 
Mientras tanto ¿Quién se enfrenta al cuadro económico devastador y quién se atreve a informarse, a hablar claro, a debatir y a tomar las decisiones difíciles respecto a las pocas opciones que aún podamos tener a nuestro alcance para concluir, de una vez y por todas, la transición de la esclavitud a la libertad, de la miseria a la bonanza, de la colonia a la república? Hoy, en este entre imperios que ya es una realidad objetiva, esa transición enfrenta el mayor peligro de retroceso en su historia. Lejos de avanzar hacia las reformas sociopolíticas que asegurarían un estado de derecho pleno, las sociedades antillanas enfrentan una escalada de violencia que hace de nuestro mar tropical uno de los lugares con las tasas más altas de inseguridad humana en todo el mundo.

\section{LOS NUEVOS FILIBUSTEROS Y LAS MAFIAS: CARA Y CRUZ DE UNA MISMA MONEDA}

Entre nosotros la arbitrariedad en el desempeño del poder y el uso de la fuerza ha sido siempre ley de vida. Pero ahora ese fenómeno cultural insoslayable se ha puesto al servicio de los grandes sindicatos del crimen organizado a escala mundial. En muchas de las islas la mafia internacional, el narco americano y las maras callejeras son una de las principales fuentes de empleo. La inseguridad ciudadana y la corrupción judicial van de la mano. Ambas crecen con fuerza en estados incapaces de ofrecer a la población, de manera consecuente y sostenida, oportunidades de trabajo decente, educación y servicios públicos de calidad.

Entre éstos servicios ningunos tienen mayor relevancia en cuanto a poner coto a la penetración del las mafias supranacionales se refiere que el buen funcionamiento de las cortes y la transparencia en el proceder de los gobernantes y los organismos de seguridad fronteriza y policíacos. Sin una judicatura fuerte y transparente en sus procederes las frágiles instituciones de los estados insulares no pueden servir de dique al torrente portentoso de la delincuencia organizada. México y Venezuela, que son estados mucho más ricos y poderosos que ninguna patria chica antillana están al límite de su capacidad de aguante en este sentido ${ }^{29}$. Caracas es la segunda ciudad más violenta del mundo y en México desollan a la gente viva en Apatzingán y es común entre los cárteles cortar las cabezas de viejos socios con sierras mecánicas de jardinería mientras éstos confiesan serenamente haberle fallado al jefe. Las islas cuelgan de estas dos argollas como una hamaca llena de agujeros incapaz de soportar el peso que se le viene encima.

\footnotetext{
${ }^{29}$ Edgardo Buscaglia ha analizado puntualmente esta problemática. Ver Buscaglia, 2013.
} 
Esos agujeros son los espacios controlados por una clase político empresarial al servicio del crimen organizado que han entrado en una relación de dependencia y servilismo en algunos casos ya mucho más extrema que la que mantenían con la metrópoli las antiguas capitanías generales o los governor generals. Las suertes de la ilegalidad producen el colapso institucional del estado vaciando de contenido todo discurso político y sembrando la muerte desde los focos insalubres de La Habana, pasando por las ruinas de Cité Soleil en Portau-Prince hasta llegar a su ápice en Laventine Hills, Puerto España donde se aprecian uno de los niveles más altos de inseguridad pública en el mundo. De esta manera acabamos siendo terreno fértil para las empresas delictivas a nivel hemisférico dedicadas al lavado del dinero y al trasiego de armas y estupefacientes, gentes y órganos, además de materia prima y desperdicios de todo tipo.

Al tanto que los países ricos se confunden todos en la lucha contra «el terrorismo», que es como se llama hoy toda fuerza que ponga en riesgo esa riqueza, el verdadero terror de estado se vive diariamente en los pueblos americanos que están a merced de las mafias y sus gobiernos. Estos engendros complejos que operan muy dentro de la economía y muy por encima de la ley son hijos de la división social tajante y se alimentan de la industria armamentista usoniana para satisfacer los placeres de consumidores insaciables en los países ricos. La mayor amenaza contra el bienestar y la felicidad de los pueblos antillanos no es el viejo espectro del imperialismo yanqui sino estas mafias que ya han entrado en casa y se despachan con la cuchara grande en la cocina. Véase México donde se anuncian los arrestos de grandes capos como «El Chapo» y «La Tuta» sin causar interrupción alguna en el negocio que estos manejaban y que pasa inmediatamente a otras manos en las más altas esferas del orden patrimonial nacional.

Pero estos no son los únicos peligros que encaran las islas con la disolución de la «Pax Usoniana». Sin duda el repliegue de Estados Unidos en el Caribe será lento y accidentado. No obstante el país nunca dejará de ejercer una influencia de peso en la zona. Por esto, una de las principales preocupaciones que surgen a raíz de esa retirada es que regrese el filibusterismo que precedió a la Guerra de Secesión de los Estados Confederados (1861-1865). Entonces los intereses usonianos se expresaron principalmente en la «iniciativa privada» de ciudadanos que, como William Walker, el Comodoro Vanderbuilt o el propio Narciso López, organizaron empresas mercantiles y expediciones militares que, rayando en la piratería, soñaron con la invitación tentadora anunciada en las Insulae Americanae de Blaeu a montar una factoría privada en un país propio donde «lo blanco» fuera ley y el rey fuera «blanco». El nuevo filibusterismo es la cara lavada de una moneda que tiene al reverso la cruz tatuada de las maras. 
Existen ya indicios de este fenómeno de rebote en la empresa y la persona de un sureño arkansés llamado Bill Clinton. Al oler la sangre en el agua y en nombre de la caridad y del desarrollo sostenible, el ex-presidente de los Estados Unidos ha logrado montar su propio país sobre las ruinas de Port-auPrince en la República de Haití. Clinton es el enviado especial de las Naciones Unidas, organismo este que, por su incompetencia en la administración de los fondos de rescate del terremoto de 2010 y el abuso de sus fuerzas militares contra la población haitiana (que incluye el haber introducido el cólera en el país), es repudiado masivamente. Clinton es también codirector de la Comisión para la Reconstrucción de Haití que ha servido de caballo de Troya para la agencia gubernamental usoniana USAID. Además es codirector del Fondo Clinton-Bush para Haití.

Todo esto hace de Bill Clinton la persona más poderosa en Haití. Sus competencias superan con creces el poder real del presidente Michel Martelly quien, fiel a la vieja usanza, es uno más en la larga lista de caciques apoyados por Washington. Los indicios de que Clinton dirige Haití como si fuera su propia factoría son preocupantes. Su modelo para el desarrollo del país, lanzado con la inauguración del Parque Industrial Caracol en Cabo Haitiano en 2012, está basado en la dependencia y en la explotación extrema de una fuerza laboral cautiva. Caracol es un complejo de maquiladoras pagado por USAID y administrado por la compañía sudcoreana Sae-A Trading levantado en una de las pocas zonas del país donde todavía quedaba tierra fértil, arable y bajo cultivo.

A la inauguración de Caracol asistió Bill acompañado de su esposa Hilary, entonces canciller de Estados Unidos y ahora candidata a la presidencia del país. Ese día el accidentado matrimonio fue la pareja perfecta: él procónsul en Haití y ella la delegada imperial de mayor rango. ¿A qué debe un país pobre y en ruinas tanta atención y cómo relacionar acaso los imperativos de la geopolítica usoniana en el Caribe con los intereses financieros de los Clinton en la primera república de Latinoamérica? Ellos dicen que lo hacen por amor y que nunca podrán olvidar lo bien que lo pasaron, allá para 1975, durante su luna de miel en el Haití de los Duvalier. ¿Quién les cree? y ¿quién duda de que el trato cerrado de los Clinton con la más alta élite haitiana y regional no incluya el coqueteo, cuanto menos a distancia, con las fuerzas ocultas de la zona tal y como se estila en México entre sus presidentes ${ }^{30}$ ?

${ }^{30}$ Ver los alegatos de Anabel Hernández en cuanto a las conexiones directas y la protección ofrecida por el presidente Felipe Calderón a Joaquín «el Chapo» Guzmán Loera, jefe de la Alianza de Sangre o Cártel de Sinaloa. Hernández, 2013. 


\section{REgReSAR AL FUTURO: LA LIGA ANTILLANA COMO LA MÁS FACTIBLE} DE LAS IMPOSIBILIDADES

Vivimos en un mundo donde las élites globalizadas y el capital se desplazan a una velocidad cada vez más vertiginosa promoviendo la monopolización de la información y del poder político. Por su parte las «masas» se sienten estancadas, desatendidas y abandonadas por los estados. Existe un sentido general de asfixia producto de una percepción a nivel global de que las cosas no andan bien. Desafortunadamente, como reflexiona Byung-Chul Han, «la actual multitud indignada es muy fugaz y dispersa. Le falta toda masa, toda gravitación, que es necesaria para acciones. No engendra ningún futuro» ${ }^{31}$. Esta dispersión, como antes he querido demostrar, es un hecho geográfico y un hito psicosocial concreto en las Antillas.

No obstante, creo que la inseguridad montante y el terror desbocado tienen el potencial de sacudirnos para obligarnos a actuar. Ante tales retos los pueblos tendrán que buscar formas de organización alternativas al simplista y obsoleto modelo del estado nacional intentando imaginar nuevos cuerpos políticos viables más allá del cadáver que nos ocupa y nos llama a entrar en su fosa. Pienso que de igual manera que los antillanos ejercemos el racismo sin tener en última instancia fe en sus postulados, también sabemos instintivamente que deben existir formas de organización social más cómodas y holgadas que la camisa de fuerza de la patria-presidio en la isla-estado. Si sabemos manejar estas contradicciones deberíamos poder superarlas. Después de todo, ¿quién niega que vivamos en sociedades machistas donde aún así, como hoy en casa del propio Fidel Castro, mandan las mujeres y que, debido en gran medida a la herencia africana que nos mueve y nos hermana, nuestra solapada preferencia por el orden matriarcal siempre haya apuntado más en la dirección de las «matrias» reales que de las patrias ideales y, por tanto, siempre más hacia las aguas en movimiento que en dirección al palo hincado en tierra?

Es por esto que, con una visión renovada, propongo volver sobre los pasos de la agenda antillanista desmochada en el 98. Refundar el proyecto confederativo es construir instituciones que reflejen y protejan la diversidad regional, es pensar en una comunidad de grupos postnacionales mixtos y en flujo e interacción continua dentro de un escenario global cada vez menos fracturado. Es por tanto rehuir de los esencialismos identitarios privilegiando la mezcla sobre la ruptura, la variabilidad constitutiva que nos hace adaptables a las circunstancias sobre la fijación reduccionista que nos condena a la obsolescencia, la irrelevancia y la muerte a nivel individual y colectivo.

\footnotetext{
31 Han, 2014: 23.
} 
Es una invitación a redibujar nuestros destinos y fronteras reclamando como patrimonio nuestro escenario marítimo vital que es, a fin de cuentas, la única forma de reconocernos asumiendo poderes reales y responsabilidades claras sobre el entorno.

Muchos dirán que el sueño de una comunidad pan-antillana es un ideal inalcanzable. Quizás sea cierto. Pero a la hora de romper con el estatus quo recordar la promesa de aquel proyecto quebrado de golpe en 1898 es una forma de darle nueva vida y, eventualmente, de reinventarlo, actualizarlo y hacer un nuevo plan de ruta. Si algo hemos aprendido muchos antillanos luego de todo un siglo de posibilidades deferidas es que el proyecto de hacer estados nacionales de los pertrechos coloniales conduce a una puja sin fin de lo que en última instancia son engendros patituertos que, más que indeseables, son verdaderamente naciones imposibles. Ahora que el poderío usoniano merma confundido y distraído por problemas apremiantes en escenarios geopolíticos distantes del Caribe, es posible retomar el curso perdido en 1898 y proponer un nuevo orden regional.

La traza general de ese nuevo patrón debe responder a las condiciones objetivas antes discutidas y hacer fuerza contra la colonialidad que vertebra el pensamiento encajonado del insularismo racialista antillano. Por eso vislumbro una confederación abierta con un una presidencia débil y rotativa en trienios. Contrastaría esto con un cuerpo legislativo supranacional, posiblemente bicameral y preferiblemente itinerante que repartiría sus competencias evitando el centralismo y la concentración de poder a nivel geográfico, lingüístico y socio-racial. El aparato político de la liga sería amparado por una judicatura fuerte capaz de asumir control real sobre un territorio amplio y geográficamente accidentado donde se permitiría el tránsito libre de los ciudadanos y productos comunitarios teniendo como prioridades la protección del medioambiente y la búsqueda del desarrollo sostenible mediante la creación de un Banco Central Antillano y otras estructuras de apoyo siguiendo el modelo establecido por el CARICOM.

A tales efectos, las gendarmerías serían competencias locales mientras que habría de establecerse una fuerza de guardacostas a nivel regional y al servicio de la judicatura central que protegería la integridad del la amplia zona de mar y las vías designadas estrictamente para el transporte marítimo y aéreo de todas las embarcaciones extranjeras. Esta jurisdicción comprendería el Mar de las Antillas definido como mar territorial, con soberanía compartida sobre los canales de Yucatán y la Florida y con los países que lo bordean en Tierra Firme desde México hasta Venezuela. Incluiría también derechos de exclusividad de doscientas millas náuticas sobre las aguas atlánticas del archipiélago de las Bahamas y las Antillas 
Menores desde la latitud $28^{\circ}$ Norte hasta la cuenca del Río Orinoco. De esta manera la Liga Antillana controlaría y aseguraría todo el acceso al Mar Caribe desde el Atlántico.

En virtud de esta nueva autoridad jurisdiccional se establecerían controles estrictos y rutas específicamente dedicadas al tránsito de mercaderías cobrando tasas competitivas para asegurar dichos corredores. Estos impuestos serían la principal fuente de ingresos del gobierno confederativo y servirían, entre otras cosas, para financiar la operación y el equipamiento de su guardia costanera marítima y aérea.

Esta vasta zona sería estrictamente desmilitarizada y estaría prohibida en ella la venta y posesión de armas de fuego entre la población civil. Asimismo, quedaría completamente inhabilitada para el transporte de todo material o equipo bélico de naciones foráneas. La Liga Antillana sería un cuerpo político estrictamente neutral quedando fuera de cualquier alianza o pacto militarista o de «defensa común».

En principio la entrada en la confederación estaría abierta a todos los estados y pueblos de la región. Sean naciones soberanas o posesiones neocoloniales todos tendrían asegurada la participación plena en una convención constituyente. Sin embargo, previo al acceso como miembros en función, los estados neo-coloniales deberán adquirir plenos poderes soberanos y rescindir cualquier compromiso adquirido o impuesto por fuerzas militares foráneas para el uso de tierras, aguas y facilidades militares en territorio antillano. La entrada en la liga de los estados independientes estará supeditada a la disolución de sus ejércitos de tierra y a la adecuación de los de aire y mar, incluyendo también sus servicios de inteligencia y espionaje, a la fuerza unificada de guardacostas bajo el mando de la judicatura confederativa y su procuradoría general.

Conforme al precedente establecido por la Unión Europea, los estados miembros de la Confederación Antillana tendrían representación propia en las Naciones Unidas y demás foros internacionales reforzando así el poder político de una zona neurálgica y cada vez de mayor relevancia para el comercio y las comunicaciones a escala global. Sus ciudadanos dispondrían de un pasaporte comunitario así como también de libertad total de movimiento y el derecho a establecer domicilio y empresa en cualquier territorio de la confederación. Cada país podría establecer relaciones políticas y tratados comerciales con potencias extranjeras siempre y cuando no entraran en violación de los derechos y potestades de la liga y su neutralidad.

La administración de los recursos minerales y energéticos de la amplia zona de mar compartido correría a cargo de un ministerio de fomento al desarrollo que apostaría por la energía renovable y la explotación sostenible 
creando a su vez amplias zonas protegidas por aire, mar y tierra. Las ganancias procedentes de estas actividades económicas serían reinvertidas en fondos comunes para la educación y adiestramiento de la población en los estados miembros.

Finalmente, tomando en cuenta los problemas heredados de las viejas divisiones territoriales y atendiendo a los reclamos de poder a escala regional, se establecería un protocolo consensuado en apoyo de la autogestión y la autodeterminación que permitiera transformar en estados propios ciudades, provincias o parroquias históricamente subordinadas a las antiguas cabeceras de las jurisdicciones coloniales. Esto contribuiría a repartir equitativamente el poder a escala regional y a promover el desarrollo económico y cultural de amplias zonas, especialmente en las Antillas mayores, que han sido relegadas y abandonadas por el centralismo ejercido durante el siglo XX desde las capitales en las patrias chicas. De esta manera Cuba, Jamaica o Puerto Rico seguirían siendo nombres de islas pero ya no de estados, que como Haití o la República Dominicana pasarían eventualmente también a la historia. Al final sería esta una apuesta por una confederación basada en un localismo activo que transforme las fronteras coloniales en una liga de ciudades estados donde se viva de cara al mar y dándole la mano al vecino.

PARA SER A UNA VEZ DIOSA DEL MAR Y REINA DEL PALMAR

El colapso institucional que se mide en la relación inversamente proporcional entre el alza en la violencia y la erosión de los derechos del ciudadano en el teatro político caribeño actual no puede ser más acorde con los intereses mercantiles de las grandes potencias globales que buscan no ya puertos sino la continuación a perpetuidad del paso libre por el Mar de las Antillas de todas sus flotas militares y mercantes. La merma del poderío usoniano está dando paso a otros actores que cada día tienen mayor peso e influencia en la zona. Superar este período de entre imperios con una solución agenciada requeriría de una intervención política inteligente y bien coordinada para reclamar control sobre el mar, compartiéndolo y custodiándolo en conjunto. Al final, esa es la única forma de garantizar a largo plazo el bienestar y la felicidad de los pueblos antillanos y caribeños.

La entrada de China en el Caribe no responde solamente a intereses comerciales de primer orden sino también a un plan geoestratégico de altura. Su intención de desplazar política y militarmente a los Estados Unidos como principal potencia militar en el Sureste Asiático encaja perfectamente con una estrategia de penetración económica y política que pretende violentar el 
cordón sanitario que protege el soft underbelly usoniano. Ese juego de tronos puede causar grandes trastornos a los pueblos antillanos y tener consecuencias devastadoras para el medioambiente de toda la cuenca del Caribe.

El plan de China está ya muy avanzado. En un principio dependió de inversiones en Panamá donde la compañía Wampong Limited, propiedad del Ejército Popular de Liberación, administra el canal desde hace años. Luego vino la construcción de una mega vía férrea entre las costas pacífica y atlántica de Colombia, proyecto que está ya en construcción. Recientemente un empresario chino de nombre Wang Jing ha puesto cincuenta mil millones de dólares sobre la mesa para abrir un nuevo canal transoceánico en Nicaragua. Hasta el momento se desconoce si Wang es un nuevo filibustero o simplemente un procónsul pues su trayectoria profesional es muy opaca. Además se estima que en menos de un año China sea ya capaz de acaparar el 20 por ciento de la capacidad de explotación de los pozos petrolíferos venezolanos. Las prestaciones que ha hecho la banca del gobierno chino a países como Cuba, Venezuela y Nicaragua suponen un endeudamiento profundo de esos pueblos a corto y mediano plazo que aseguran la permanencia y el continuo crecimiento del poderío chino en la zona a largo alcance.

Sin duda, para mediados del siglo si no antes, China habrá de reemplazar a los Estados Unidos como el principal comprador de Petróleos de Venezuela para controlar efectivamente las mayores reservas de hidrocarburos del mundo. Si no se da un cambio de curso radical países como Venezuela, México, Panamá, Nicaragua y Cuba acabarán endeudados con la nueva superpotencia global más allá de toda posibilidad de pago en divisa. Como ya se rumora en la prensa hongkonesa, esos países tendrán entonces que pagar en concesiones territoriales y China pasaría a asumir soberanía de islas e islotes en las Antillas siguiendo el precedente sentado por los portugueses en Macao y los ingleses en Hong Kong ${ }^{32}$. Estados Unidos tendrá mucho que decir y mucho más que probar frente a unos negocios tan sucios como los que llevaron al país hace un siglo a ser dueño en perpetuidad de la Bahía de Guantánamo y de las islas de Mona, Puerto Rico, Culebra, Vieques, Santo Tomás, Santa Cruz y San Juan, entre otras.

La invasión financiera y tecnológica china ha venido acompañada de una colonización profunda y extensa de la infraestructura comercial en puntos estratégicos de la zona. Ya hay lugares en la Cuenca del Caribe, como Belice, donde la mayor parte del comercio de ultramarinos de los grandes y pequeños almacenes está directamente en manos de comerciantes chinos. Los beliceños,

32 Esta información la sustraigo de conversaciones privadas mantenidas con Dong Jingsheng, Director del Centro de Estudios Latinoamericanos de la Universidad de Pekín. 
sintiéndose económicamente desahuciados en su propio país y víctimas de los precios fijados por éstos cárteles de venta a mediana escala y al detal, se desquitan con pintar grafiti a lo largo de las calles de Dandriga y Ciudad de Belice siguiendo la variante «R.I.P. Chen». ¿Será esta la consigna, pintada por las maras y no por las guerrillas, que reemplace al "Yanqui go home!" en las islas?

Al hablar de la expansión de los intereses chinos no pretendo pintar un cuadro desolador y menos aún ser alarmista. A falta de un plan de autogobierno regional los peores enemigos de los pueblos antillanos seguirán siendo los antillanos mismos. Queda claro que los vacíos de poder siempre se llenan. Por esto propongo que el viejo orden de las Insulae Americanae que ofrecía las islas como premio al mejor postor, suplantado como fue por la «Pax Usoniana» que las dividió para conquistarlas, debe dar paso finalmente a una Paz Antillana que las unifique, las defienda y las haga partícipes en propiedad de las profundas transformaciones geopolíticas que se gestan en el mundo.

La única forma por medio de la cual países pequeños pueden llegar a tener injerencia en el mundo globalizado es aunando sus fuerzas para negociar con los grandes, no de uno en uno, sino haciendo un balance delicado y en conjunto de todas las fuerzas sobre el tablero de juego. Ahora que el Mar de las Antillas ha dejado de ser un campo de acción exclusivamente usoniano, la Confederación Antillana tendría que surgir para promover la felicidad de sus pueblos en función del equilibrio entre los intereses de las grandes potencias globales en la zona. Tendrá también que negociar con los pueblos del Gran Caribe, especialmente con Colombia, Panamá y Nicaragua un arreglo mutuamente beneficioso para repartir las obligaciones y las ganancias de la que está próxima a convertirse en una de las mayores vías de paso transoceánica del mundo gracias a las nuevas obras de infraestructura a gran escala que están siendo proyectadas y construidas en esos países con capital chino.

Cualquier otro desenlace sería desastroso en tanto supondría la profundización de patrones de violencia cada vez más terroríficos en el nombre del saqueo generalizado. Solo el resurgimiento de una Liga Antillana renovada podría asegurar la transición de esta nueva etapa de entre imperios, que es ya una realidad tangible en la zona, a una era verdaderamente postcolonial. Así se cumpliría finalmente con el reclamo de Betances, «las Antillas para los hijos de las Antillas», máxima que pasaría a ser reinterpretada en función del territorio común compartido una vez que las hijas e hijos de las islas tomasen posesión del mar que lleva su nombre y que pasaría a ser en propiedad y en toda ley, finalmente, un mar antillano y caribeño. 


\section{BiBLIOGRAFÍA}

Beckles, Hilary McDonald, Britain's Black Debt: Reparations for Caribbean Slavery and Native Genocide, Kingston, University of the West Indies Press, 2013.

Benítez Rojo, Antonio, La isla que se repite: el Caribe y la perspectiva postmoderna, San Juan, Editorial Plaza Mayor, 2010.

Buscaglia, Edgardo, Vacíos de Poder en México: Cómo combatir la delincuencia organizada, México, Debate, 2013.

Buscaglia Salgado, José, "El poder, la ideología y el terror en el Mar de las Antillas", José Antonio Piqueras y Consuelo Naranjo Orovio (eds.), Historia de las Antillas, vol. 5., Madrid, Doce Calles, 2014: 475-517.

Buscaglia Salgado, José, "El Caribe al final de la Era Usoniana: Hacia un nuevo modelo de confederación”, Aguaita, 23 (Cartagena de Indias, diciembre 2011): 38-58.

Buscaglia Salgado, José, Undoing Empire, Race and Nation in the Mulatto Caribbean, Minneapolis, University of Minnesota Press, 2003.

Césaire, Aimé, Para leer a Aimé Césaire, Philippe Ollé-Laprine (int.), México, Fondo de Cultura Económica, 2008.

Dávila, Virgilio, “Redención”, Obras completas, San Juan, Editorial Cordillera, 1964: 26.

Fuentes, Norberto, Dulces guerreros cubanos, Barcelona, Seix Barral, 1999.

Go, Julian, American Empire and the Politics of Meaning: Elite Political Cultures in the Philippines and Puerto Rico during U.S. Colonialism, Durham, Duke University Press, 2008.

Han, Byung-Chul, El enjambre, Barcelona, Herder, 2014.

Helg, Aline, Our Rightful Share: The Afro-Cuban Struggle for Equality, 1886-1912, Chapel Hill, The University of North Carolina Press, 1995.

Hernández, Anabel, México en llamas: el legado de Calderón, México, Grijalvo, 2013.

Hostos, Eugenio María de, Obras completas, San Juan, Editorial Coquí, 1969.

Hulme, Peter, Colonial Encounters: Europe and the Native Caribbean, 1492-1797, New York, Routledge, 1992.

Keim, De Benneville Randolph, San Domingo: Pen Pictures and Leaves of Travel, Romance and History, from the Portfolio of a Correspondent in the American Tropics, Filadelfia, Claxton, Remsen \& Haffelfinger, 1870.

Martí, José, “Odio el mar”, Roberto González Echevarría (int.), Esther Allen (trad.), Selected Writtings, Nueva York, Penguin Books, 2002: 66.

Pedreira, Antonio S., Insularismo, Mercedes López-Baralt (ed.), San Juan de Puerto Rico, Plaza Mayor, 2001. 
Piñera, Virgilio, "La isla en peso", Mark Weiss (trad.), La Isla en peso/The Whole Island, Exeter, Shearsman Books, 2010.

Ponte, Antonio José, Tales from the Cuban Empire, Cola Franzen (trad.), San Francisco, City Lights Publishers, 2002.

Quijano, Aníbal, “Colonialidad del poder, eurocentrismo y América Latina”, Edgardo Lander (ed.), La colonialidad del saber: eurocentrismo y ciencias sociales. Perspectivas latinoamericanas, Buenos Aires, Consejo Latinoamericano de Ciencias Sociales, 2000: 201-246.

Thornike, Tony, "Politics and Society in the South-Eastern Caribbean", Society and Politics in the Caribbean, Colin Clarke (ed.), Nueva York, St. Martin's Press, 1991: 110-130.

Fecha de recepción: 9 de septiembre de 2014.

Fecha de aceptación: 29 de diciembre de 2014.

\section{The Antilles, once again, "between empires" and on how to confront racialist insularism to reach the goal of a regional confederation}

At the start of the 21st century the peoples of the Antilles once again find themselves as minor actors in a process of global geopolitical restructuring where the Caribbean is a scenario of major relevance. A new period "between empires" is coming into focus with the retreat of the United States and the rise in the influence of China in the region. This work is a broad reflection that, at the intersection of history, cultural studies and macropolitics, reclaims the legacy of the $19^{\text {th }}$ century project for the creation of the Antillean Confederation to posit a possible realignment of forces at the regional level that would favor the possibility of breaking with the insularism complex, the culture of racialism and half a millennium of political subjection to foreign powers.

Key words: Antilles; Antillean Confederation; Antillean League; Caribbean; China; Insularism; Racialism; Racism; Monroe Doctrine; West Indies. 